\title{
GRAIN SIZE AND HEAVY MINERAL ANALYSES OF TWO BOREHOLES IN RECENT TO MIOCENE AQUIFER IN BENIN FORMATION
}

\author{
O. I. Imasuen', 0. M. Omorogieva ${ }^{2,}{ }^{*}$ and N. J. Nwokoloh ${ }^{3}$ \\ 1, 2 Department of Geology, University of Benin, Benin City. Edo STATE. NigERIA \\ 3 Delta State Ministry of Water Resources, Awin Road, Asaba, Delta State, NiGERIA \\ E-mail addresses: ${ }^{1}$ okpeseyi.imasuen@uniben.edu, ${ }^{2}$ osakpolor.omorogieva@physci.uniben.edu, \\ 3 maillazie@yahoo.com
}

\begin{abstract}
Recent studies have revealed that groundwater contamination is dependent on the porosity and permeability of the overlying and underlying bed rocks and the mineral composition of the aquifer geometry with respect to depth. This study became important due to several reports on groundwater contamination and in order to understand the mineral composition and the grain sizes of the aquifer in the study areas. Two boreholes were drilled 4.2km apart; one at Okabere and the other at Evbuabogun community both in Ikpoba-Okha Local Government Area of Edo State. The communities have been merged with the capital city as a result of urbanization and population growth. Grain size and heavy mineral analyses were carried out on the soil samples collected from the boreholes at an interval of 15ft. The results obtained indicate that the heavy minerals in Okabere borehole is dominated by Zircon, Tourmaline, Rutile, Biotite and Garnet while Evbuababegun borehole is mainly of Zircon, Kyanite, Rutile, Staurolite, Garnet and Tourmaline which indicate that the sediments were of igneous and metamorphic origin. Grain size analysis of both wells show that mean, inclusive standard deviation, skewness and kurtosis generally indicates very coarse sand to medium sand; very well sorted to moderately sorted and very platykurtic in nature. The foregoing revealed that the aquifer geometry of the study areas is unconfined and vulnerable to contamination. It is recommended that groundwater quality assessment study should be carried out in order to determine the potability of the groundwater bodies.
\end{abstract}

Keywords: grain size, heavy minerals, borehole, aquifer, Benin formation

\section{INTRODUCTION}

Sedimentology is of increasing importance in environmental research, particularly environmental pollution studies, where past trends in environmental processes need to be combined with data on present conditions to predict likely future changes-the past and present as a key to the future [1]. Sedimentology is an important branch of geology and its use in Water resources management, pollution studies of underground water bodies and depositional environment cannot be over emphasized. The assumptions that groundwater is clean and drilling should be done blindly are acts of ignorance and the consequences far outweigh the benefits.Basic sedimentological data should form part of any assessment of potentially contaminated sites and part of investigations into the dispersion and trapping of contaminants in fluvial systems. These data are also required for rational environmental management to ensure that planning decisions are compatible with natural environmental constraints [1]. Sedimentological examination of subsurface borehole sediments play a major role in groundwater study and help to decipher the depositional environment using basic principles of geology[1-4]. The stratigraphy of a terrain plays an important role in groundwater contamination especially when the aquifer geometry is unconfined [5-7]. If an aquifer is unconfined and shallow, there is a high probability of vulnerability to contaminants of whatever source and kind, especially when they are close to area of high population density with high anthropogenic activities [8]. Omorogieva

* Corresponding author, tel: +234-803-680-1978 
and Imasuen [9], Joshua and Oyebanjo [10] revealed that sediments originate from the near surface, exposed igneous, volcanic and sedimentary rocks. Some of these are easily eroded, whereas others, especially the crystalline and metamorphic rocks, are affected by streams only when altered in the surface [11]. In line with the mandate of World Health Organization (WHO) and United Nations Children Education Fund (UNICEF) for everyone to have access to clean water under the programme of Water Sanitation and Health (WASH) particularly children and those living in the rural community and suburb. This study was initiated in order to evaluate the stratigraphy and heavy mineral composition of sediments from two boreholes in two notable communities in Benin City, Edo State, Nigeria. The study contributes to groundwater system in the area, facilitates policy maker in their decision making process with respect to environmental management plans, groundwater protection and management of the study area in particular and the world in general.

\section{METHODOLOGY}

Evbuabogun and Okabere are suburb communities within Benin metropolis and are located on the coordinates N $06^{\circ} 1.6^{\prime} 23.6^{\prime \prime}$ and E $005^{\circ} 39^{\prime} 38.9^{\prime \prime}$ and $\mathrm{N}$ $06^{\circ} 1.6^{\prime} 23.6^{\prime \prime}$ and E $005^{\circ} 39^{\prime} 38.6^{\prime \prime}$ with an elevation of 76 and 85 meters above sea level (ASL) and depths of $45.72 \mathrm{~m}$ and $54.86 \mathrm{~m}$ respectively. Geologically, the study area falls within the Benin Formation $[12,13]$. The communities are residential quarters and the inhabitants depend largely on groundwater for consumption. Two boreholes were drilled at Evbuabogun and Okabere separated by a distance of $4.2 \mathrm{~km}$ (Fig. 1). Sample were collected at $15 \mathrm{ft}$ interval and subjected to grain size and heavy mineral analyses with the aim of evaluating the lithology, grain size distribution and heavy mineral composition in order to determine the aquifer geometry, source of sediment and its vulnerability to groundwater contamination. The boreholes were drilled manually using rotary method [14] while the grain size and mineral analyses were analyzed using the standard procedure as proposed by Folk [15]; Krishna [16]; Petti John et al., [17]; Rao et al., [18]; Anfuso et al., [19] and Feo-Codecido [20]. The results obtained in weight and cumulative weight percentages respectively were represented in tables. The probability cumulative curves were used to obtain statistical parameters under the phi (Ø) system. These parameters were obtained using the formulae for statistical parameter of grain size [21]. The grain size of sediment depend largely on the character of the source rocks, weathering processes, abrasion and selective sorting during transportation. Sediment particles are segregated according to their hydrodynamic behaviour and depend mainly on the particle size. Mean grain size is a reflection of the competency of the transporting system $[22,23]$.

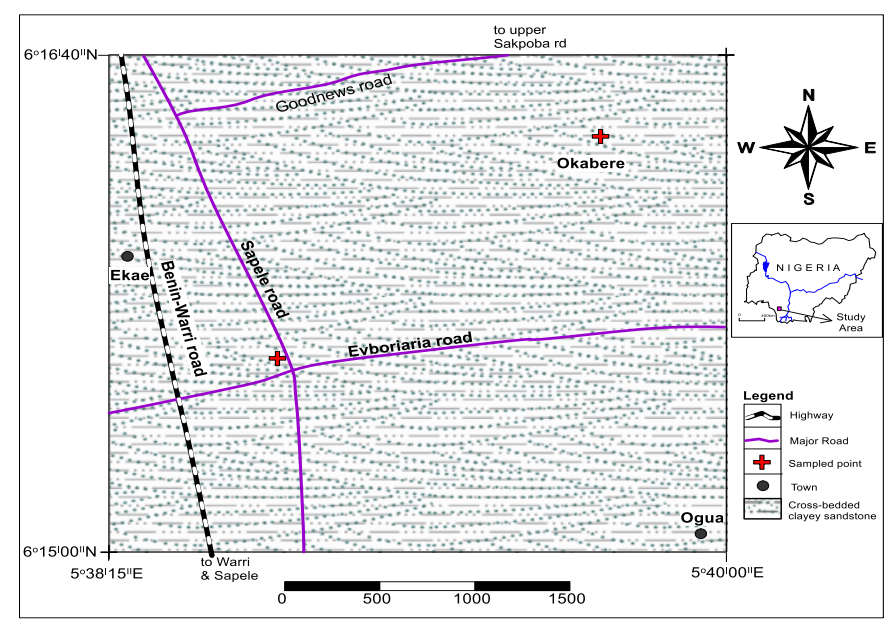

Fig. 1: Location map of the study area

\section{RESULTS AND DISCUSSION}

The results obtained from grain size analysis were used to calculate the cumulative weight percent which was plotted against the phi values to obtain curves for each of the sample. From the probability cumulative curves, values of $\varnothing 5, \varnothing 16, \varnothing 25, \varnothing 50, \varnothing 75, \varnothing 84$ and $95 \varnothing$ were obtained (Table 1 and 2) and used in the calculation of mean, inclusive standard deviation, inclusive skewness and kurtosis (Table 3 and 4).Table 4 and 5 summarizes the mean, inclusive standard deviation, inclusive skewness, kurtosis and lithologic description of the two wells respectively. The results indicate that the grain size werecoarse sand; moderately to well sorted, coarse skewed and platykurtic (Table 4 and 5).The description above suggests a fluvial environment of deposition with moderate to high energy[23,26]. The sequence fine upward which implies that the aquifers are protected from contamination but this may not be correct as the litho log and grain size analysis revealed that subsurface strata were poor of clay materials. The values obtained from the inclusive standard deviation for Evbuabogun well, range from -0.08 to 0.840 with an average of 0.484 (Table4), the grain size are well sorted, an indication that the sediments have travelled an average distance from the source but not long enough distance to achieve a very good sorting. 
Table 1: Summary of Percentile values drawn from the Cumulative Probability Curve for Evbuabogun Well

\begin{tabular}{cccccccc}
\hline Depth (ft) & $\varnothing 5$ & $\varnothing 16$ & $\varnothing 25$ & $\varnothing 50$ & $\varnothing 75$ & $\varnothing 84$ & $\varnothing 95$ \\
\hline $0-15$ & -0.55 & 0.1 & 0.4 & 1.0 & 1.7 & 1.9 & 2.6 \\
$16-30$ & -0.6 & 0.0 & 0.4 & 0.9 & 1.6 & 1.9 & 2.6 \\
$30-45$ & -1.9 & -0.4 & -0.1 & 0.7 & 1.3 & 1.6 & 2.4 \\
$46-60$ & -0.4 & 0.05 & 0.3 & 0.8 & 1.25 & 1.5 & 2.0 \\
$61-75$ & -0.5 & -0.15 & 0.3 & 1.0 & 1.5 & 1.8 & 2.3 \\
$76-90$ & -2.4 & -1.5 & -1.0 & 0.0 & 1.0 & 1.3 & 2.2 \\
$91-105$ & -0.3 & 0.2 & 0.5 & 1.0 & 1.6 & 1.85 & 2.4 \\
$106-120$ & -0.6 & 0.0 & 0.3 & 1.0 & 1.7 & 2.1 & 2.7 \\
$121-135$ & -0.8 & -0.35 & -0.2 & 0.2 & 0.7 & 0.9 & 1.25 \\
$136-150$ & -1.6 & -1.1 & -0.8 & -0.2 & 0.3 & 0.6 & 1.0 \\
\hline
\end{tabular}

Table 2: Summary of Percentile values drawn from the Cumulative Probability curve for Okabere

\begin{tabular}{cccccccc}
\hline Depth (ft) & $\varnothing 5$ & $\varnothing 16$ & $\varnothing 25$ & $\varnothing 50$ & $\varnothing 75$ & $\varnothing 84$ & $\varnothing 95$ \\
\hline $0-15$ & -0.5 & 0 & 0.2 & 0.8 & 1.2 & 1.8 & 2.0 \\
$16-30$ & -0.8 & 0.4 & 0.8 & 1.2 & 1.7 & 2.0 & 2.6 \\
$30-45$ & -0.6 & 0.3 & 0.7 & 1.5 & 1.4 & 1.9 & 2.1 \\
$46-60$ & -0.5 & 0.0 & 0.3 & 0.8 & 1.2 & 1.5 & 2.0 \\
$61-75$ & -0.5 & 0.0 & 0.2 & 0.8 & 1.3 & 1.6 & 2.0 \\
$76-90$ & -1.0 & -0.3 & -0.1 & 0.5 & 1.1 & 1.3 & 1.9 \\
$91-105$ & -0.5 & 0.0 & 0.2 & 0.8 & 1.25 & 1.5 & 2.0 \\
$106-120$ & -1.0 & -0.4 & -0.1 & 0.6 & 1.2 & 1.8 & 2.1 \\
$121-135$ & -0.7 & -0.3 & -0.1 & 0.3 & 0.7 & 0.85 & 1.3 \\
$136-150$ & -1.1 & -0.6 & -0.3 & 0.15 & 0.6 & 0.85 & 1.3 \\
$151-165$ & 0.2 & 0.6 & 0.75 & 1.1 & 1.4 & 1.6 & 2.0 \\
$166-180$ & -1.6 & -1.15 & -1.0 & -0.4 & 1.15 & 0.4 & 0.9 \\
\hline
\end{tabular}

On the other hand, the values obtained from inclusive standard deviation for Okabere well range from -0.41 to 0.68 with an average of 0.4836 (Table 3) which indicates moderately well sorted sediments which have travelled less distance than the sediments of Evbuabogun; since sorting improve with distance travelled by the sediments. The result also implies that the transportation of the sediments is from Okabere to Evbuabogun which further buttress the microscopic results obtained for Evbuabogun and Okabere wells (Table 5 and 6) respectively.

In the computations shown in Tables 3 and 4, the following formulae were used:

$$
\begin{gathered}
\text { mean }=\frac{\phi 16+\phi 84+\phi 50}{3} \\
\text { Standard Deviation }=\frac{\phi 84-\phi 16}{4}+\frac{\phi 95-\phi 5}{6.6} \\
\text { Skewness }=\frac{\phi 95-\phi 5}{2.44(\phi 75-\phi 25)} \\
\text { Kurtosis }=\frac{\phi 16+\phi 84-2 \phi 50}{2(\phi 84-\phi 16)} \\
+\frac{\phi 5+\phi 95+2 \phi 50}{2(\phi 95-\phi 5)}
\end{gathered}
$$

The lithology of both wells are similar but vary in certain areas, Okabere well has shale intercalations which thins out towards Evbuabogun. The heavy mineral studies revealed that zircon, tourmaline, garnet, rutile, staurolite are dominant and their presence indicate that the sediments originated from a basement complex rock [11, 16, 24-25]. In Okabere well, zircon is the most dominant mineral with $38.71 \%$ and rutile $22.58 \%$ respectively (Fig. 3 ).

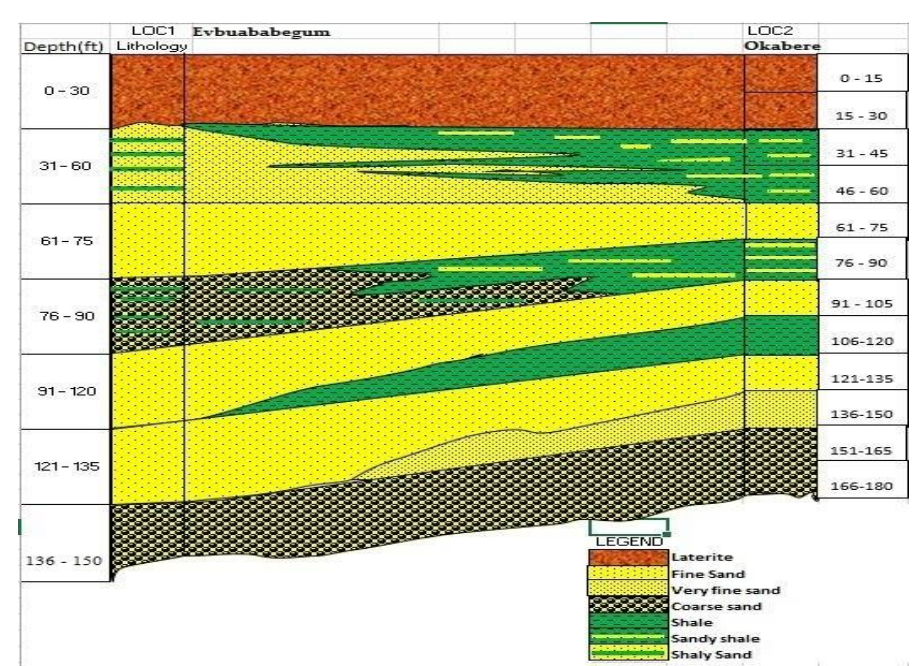

Fig. 2: Correlation and lithologic description of the two wells (boreholes)
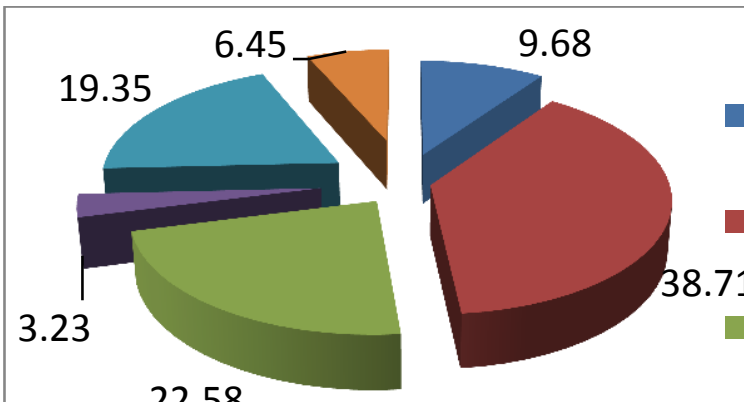

kyanite

Zircon

22.58

Fig. 3: Percentage composition of all minerals in Okabere well

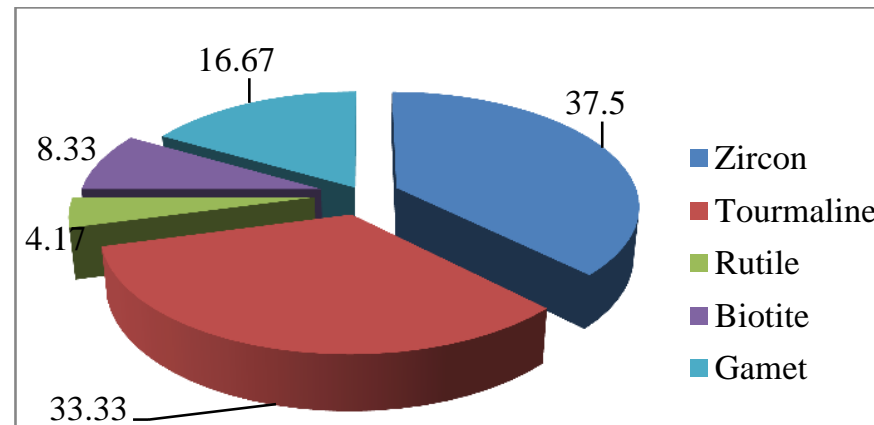

Fig. 4: Percentage composition of all minerals present in Evbuabogun well 
Table 3: Result of the Grain Size Analysis of Okabere Well

\begin{tabular}{|c|c|c|c|c|c|c|}
\hline $\mathrm{S} / \mathrm{N}$ & $\begin{array}{c}\text { Depth } \\
(\mathrm{ft})\end{array}$ & mean & $\begin{array}{c}\text { Std } \\
\text { deviation } \\
\end{array}$ & Skewness & Kurtosis & Description \\
\hline 1. & $0-15$ & 0.870 & 0.680 & 0.038 & 0.614 & $\begin{array}{l}\text { Coarse sand, moderately towell sorted, coarse skewed, } \\
\text { platykurtic. }\end{array}$ \\
\hline 2. & $16-30$ & 1.200 & 0.670 & 0.667 & 0.820 & $\begin{array}{l}\text { Medium sand, moderately well sorted, strongly coarse } \\
\text { skewed, platykurtic. }\end{array}$ \\
\hline 3. & $31-45$ & 0.710 & 0.650 & 0.522 & 0.574 & $\begin{array}{l}\text { Coarse sand, moderately well sorted, strongly coarse } \\
\text { skewed, platykurtic. }\end{array}$ \\
\hline 4. & $46-60$ & 0.770 & 0.600 & -0.067 & 0.683 & $\begin{array}{l}\text { Coarse sand, moderately well sorted, strongly coarse } \\
\text { skewed, platykurtic. }\end{array}$ \\
\hline 5. & $61-75$ & 0.800 & 0.630 & 0.367 & 0.559 & $\begin{array}{l}\text { Coarse sand, moderately well sorted, strongly coarse } \\
\text { skewed, very platykurtic. }\end{array}$ \\
\hline 6. & $76-90$ & 0.500 & 0.390 & -0.056 & 0.369 & $\begin{array}{l}\text { Coarse sand, well sorted, strongly fine skewed, very } \\
\text { platykurtic. }\end{array}$ \\
\hline 7. & $91-105$ & 0.770 & 0.600 & -0.067 & 0.585 & $\begin{array}{l}\text { Coarse sand, moderately well sorted, strongly fine } \\
\text { skewed, very platykurtic. }\end{array}$ \\
\hline 8. & $106-120$ & 0.670 & 0.520 & 0.240 & 0.410 & $\begin{array}{l}\text { Coarse sand, moderately well sorted, coarse skewed, } \\
\text { very platykurtic. }\end{array}$ \\
\hline 9. & $121-135$ & 0.280 & 0.210 & -0.322 & 0.342 & $\begin{array}{l}\text { Coarse sand, very poorly sorted, strongly fine skewed, } \\
\text { very platykurtic. }\end{array}$ \\
\hline 10. & $136-150$ & 0.130 & 0.090 & -0.350 & 0.273 & $\begin{array}{l}\text { Coarse sand, very well sorted, strongly fine skewed, } \\
\text { very platykurtic. }\end{array}$ \\
\hline 11. & $151-165$ & 1.100 & 0.520 & 0.100 & 1.135 & $\begin{array}{l}\text { Medium sand, moderately well sorted, fine skewed, } \\
\text { leptokurtic. }\end{array}$ \\
\hline 12. & $166-180$ & 0.380 & -0.410 & 2.105 & -1.912 & $\begin{array}{l}\text { Very coarse sand, very well sorted, strongly coarse } \\
\text { skewed, very platykurtic. }\end{array}$ \\
\hline
\end{tabular}

Zircon also dominates Evbuabogun well with 37.50\% while tourmaline was the second in abundance with $33.33 \%$. Some of the heavy minerals were subrounded which suggest that the sediments were reworked. Zircon is colorless to light pink, pyramidal, rounded to sub rounded and broken fragments of sub angular (Fig. 4 and 6). Tourmaline is honey-yellow to light brown and pale green to dark grey, pyramidal, angular to sub-angular prismatic grains while rutile is deep brick-red to honey-yellow, sub angular to sub rounded, weakly pleochroic and constitutes $22.58 \%$ of the heavy mineral assemblages in Okabere and $4.17 \%$ in Evbuabogun wells respectively. Other heavy minerals in this study include biotite which constitutes $8.33 \%$ of the heavy mineral assemblage in
Evbuabogun well they are flaky grains and are paleyellow to reddish-brown in colour. Garnet is one of the least dominant heavy mineral, constituting $16.16 \%$ of the heavy mineral assemblage in Evbuabogun well; the grains are colourless to pale brown in colour. Kyanite constitutes $9.68 \%$ of the heavy mineral assemblage in Okabere well. It occurs as elongated, colourless grains with rectangular outline. It does not show much variation and are sub-angular to subround while Staurolite constitutes $3.23 \%$ of the heavy minerals found in Okabere well. Staurolite grains exhibit various tints of golden yellow and brown colour and occur as sub-angular to sub-round broken fragments (Fig. 3 and 5). 
Table4: Result of the grain size analysis of Evbuabogun well.

\begin{tabular}{|c|c|c|c|c|c|c|}
\hline $\mathrm{S} / \mathrm{N}$ & Depth (ft) & Mean & $\begin{array}{c}\text { Std } \\
\text { deviation }\end{array}$ & Skewness & Kurtosis & Description \\
\hline 1. & $0-15$ & 1.000 & 0.760 & 0.012 & 0.646 & $\begin{array}{l}\text { Very fine gravel, moderately sorted, } \\
\text { fine skewed, very platykurtic. }\end{array}$ \\
\hline 2. & $16-30$ & 0.930 & 0.760 & 0.053 & 0.649 & $\begin{array}{l}\text { Coarse sand, moderately sorted, fine } \\
\text { skewed, very platykurtic. }\end{array}$ \\
\hline 3. & $31-45$ & 0.900 & 0.560 & -0.775 & 0.409 & $\begin{array}{l}\text { Coarse sand, moderately well } \\
\text { sorted, strongly coarse skewed, very } \\
\text { platykurtic. }\end{array}$ \\
\hline 4. & $46-60$ & 0.780 & 0.600 & 0.248 & 0.690 & $\begin{array}{l}\text { Coarse sand, moderately well } \\
\text { sorted, coarse skewed, platykurtic. }\end{array}$ \\
\hline 5. & $61-75$ & 0.880 & 0.690 & -0.172 & -0.034 & $\begin{array}{l}\text { Coarse sand, moderately well } \\
\text { sorted, coarse skewed, very } \\
\text { platykurtic. }\end{array}$ \\
\hline 6. & $76-90$ & -0.06 & -0.080 & -1.200 & -0.164 & $\begin{array}{l}\text { Very coarse sand,very well sorted, } \\
\text { coarse sand, very platykurtic. }\end{array}$ \\
\hline 7. & $91-105$ & 1.017 & 0.720 & 0.039 & 0.782 & $\begin{array}{l}\text { Medium sand, moderately sorted, } \\
\text { fine skewed platykurtic. }\end{array}$ \\
\hline 8. & $106-120$ & 1.030 & 0.840 & 0.429 & 0.615 & $\begin{array}{l}\text { Medium sand, moderately sorted, } \\
\text { strongly fine skewed, very } \\
\text { platykurtic. }\end{array}$ \\
\hline 9. & $121-135$ & 0.250 & 0.210 & 0.192 & 0.369 & $\begin{array}{l}\text { Coarse sand, very well sorted, } \\
\text { coarse skewed, very platykurtic. }\end{array}$ \\
\hline 10. & $136-150$ & -0.230 & -0.222 & -3.800 & -2.552 & $\begin{array}{l}\text { Very coarse sand, very well sorted, } \\
\text { strongly fine skewed, very } \\
\text { platykurtic. }\end{array}$ \\
\hline
\end{tabular}

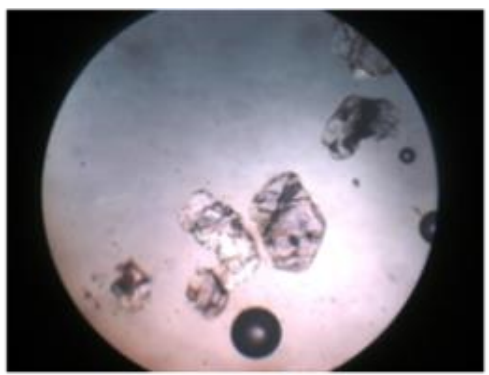

a. Zircon

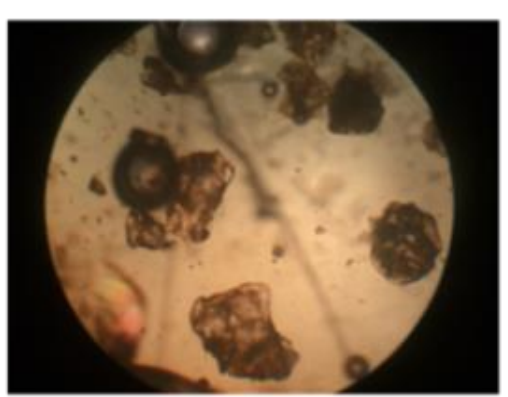

d. Rutile

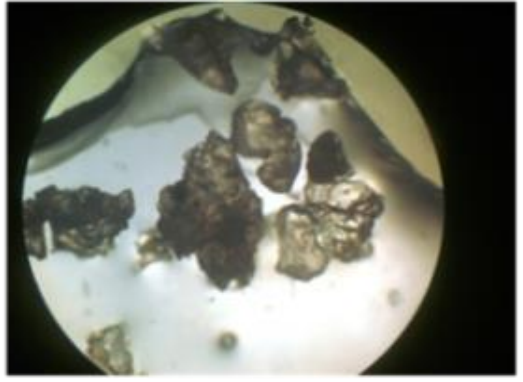

b. Kyanite

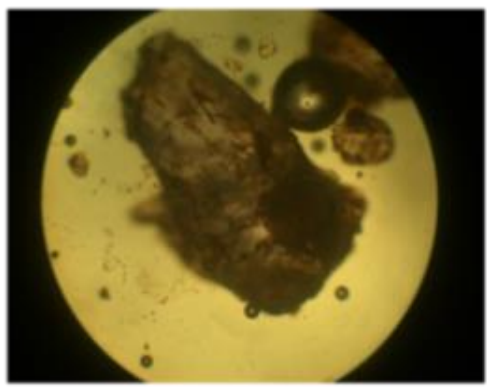

e. Rutile

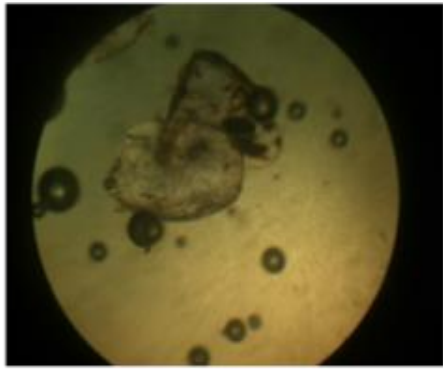

c. Tourmaline

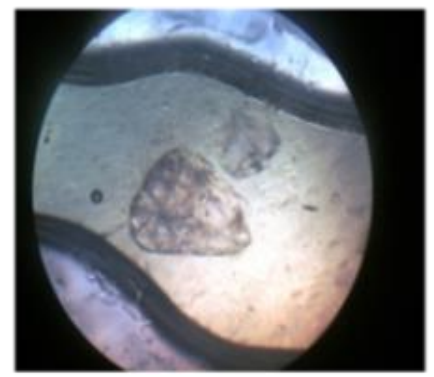

f. Garnet

Fig. 5: Petrographic analysis of heavy mineral in Okabere well 


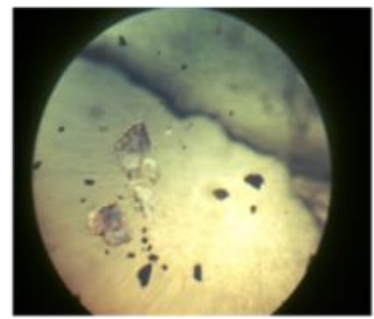

a. Zircon

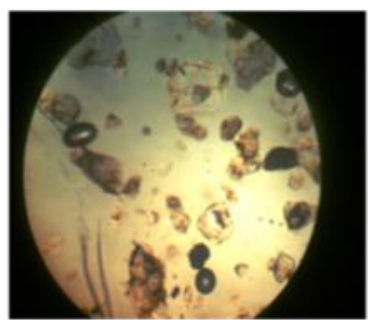

d. Staurolite

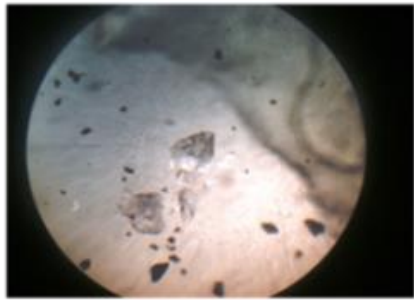

b. Zircon

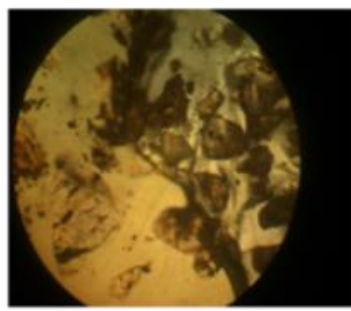

e. Rutile

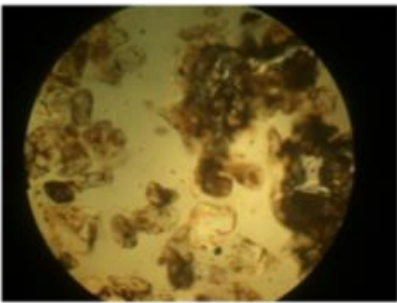

c. Tourmaline

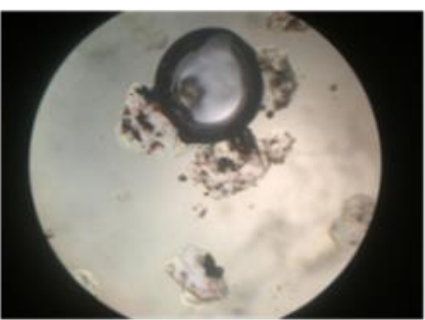

f. Garnet

Fig. 6: Result of the petrographic analysis of Evbuabogun well.

Table 5: Result of the morphoscopic analysis of Okabere well

\begin{tabular}{lllll}
\hline S/N & Depth $(\mathrm{ft})$ & Lithology & Colour & Shape \\
\hline 1. & $0-15$ & Sand & Reddish & Sub rounded to rounded. \\
2. & $16-30$ & Fine sand & Reddish & Rounded. \\
3. & $31-45$ & Medium to coarse sand & Dark brown & Sub rounded \\
4. & $46-60$ & Medium to coarse sand & Light brown & Sub rounded. \\
5. & $61-75$ & Medium sand & Light brown & Sub rounded. \\
6. & $76-90$ & Medium sand & Light brown & Rounded. \\
7. & $91-105$ & Medium sand & Light brown & Sub rounded. \\
8. & $106-120$ & Medium sand & Light brown & Sub rounded. \\
9. & $121-135$ & Coarse sand & White sand. & Rounded. \\
10. & $136-150$ & Coarse sand & Milkish & Sub rounded. \\
11. & $151-165$ & Very fine sand. & Milkish & Rounded. \\
12. & $166-180$ & Very coarse sand & Light brown. & Sub rounded. \\
\hline
\end{tabular}

Table 6: Result of the morphoscopic analysis of Evbuabogun well

\begin{tabular}{lllll}
\hline S/N & Depth $(\mathrm{ft})$ & Lithology & Colour & Shape \\
\hline 1. & $0-15$ & Very fine Sand & Reddish & Rounded. \\
2. & $16-30$ & Fine sand & Reddish & Rounded. \\
3. & $31-45$ & Medium sand & Reddish brown & Sub rounded \\
4. & $46-60$ & Medium sand & Reddish brown & Rounded. \\
5. & $61-75$ & Medium sand & brownish & Sub rounded. \\
6. & $76-90$ & Coarse sand & Brownish & Sub angular to angular. \\
7. & $91-105$ & Fine sand & Milkish white & Sub rounded to rounded. \\
8. & $106-120$ & Fine sand & Milkish white & Sub rounded to rounded. \\
9. & $121-135$ & Coarse sand & Milkish & Sub rounded to rounded. \\
10. & $136-150$ & Coarse sand & Milkish & Sub rounded to rounded. \\
\hline
\end{tabular}

\section{CONCLUSION}

The grain size analysis revealed that the sediments are composed of medium to coarse grain sands while morphoscopic study revealed that the grain sizes were rounded to sub rounded which suggest closeness to sediment sources. The sediments from Evbuabogun well are slightly more rounded than those from Okabere well; this indicates that Okabere well is closer 
to the parent rock while Evbuabogun well is further away from the parent rock based on the degree of roundness. The degree of roundness reflects the distance of transportation; hence the sediments can be inferred to be slightly mature to sub mature for both wells while the direction of transportation of the sediments is suggested to be from Okabere to Evbuabogun well based on the degree of roundness. The coarse to fine grain sands indicate a low to moderately high energy during transportation to depositional site for both wells. The heavy mineral analysis shows a dominance of Zircon, Tourmaline, Rutile, Garmet and Staurolite; these heavy minerals found in both wells are associated with igneous and metamorphic source which indicates that sediments from both wells are from basement complex rock. Ultimately, the results obtained in this study shows that groundwater within the study area is likely to be vulnerable to contamination as a result of the absence of clay materials capping the aquifer; however, groundwater quality assessment need to be carried out in order to ascertain the dportability of the groundwater resources.

\section{REFERENCES}

[1] Brandly, E and David, M. Implication of Sedimetological Studies for Environment and Management: Examples from Fluvial Systems in North Queensland and West Australia. Sedimentary Geology, Vol. 85 (1-4) pp 235-252. (1993).

[2] Nwajide, C. S. A guide for geological field trip to Anambra and related sedimentary basins in southeastern. University of Nigeria, Nsukka pp. 28. (2006).

[3] Tawari, G. S. Variation of heavy minerals in different lithofacies and Geomorphic Units of Ganga - Yamuna River near their confluence at Allahabad, Uttar Pradesh". Geol. Soc. India, 71, Pp133-140, (2008,).

[4] Suzuki, T. Heavy minerals composition of the Recent sediments in 3 different Environments in Geological survey of Japan part, Vol.1, pp 501. (1975).

[5] Onyeobi, T. U. S and Akujieze, C.N.. Characterization of Soil and Sediment Parameters of Jisike-Izombe Upper Aquifer System for Assessment of Potential of Groundwater Pollution. J. Appl. Sci. Environ. Manage, Vol. 18 (4) pp674-683. (2014).

[6] Akpoborie I. A. Aspect of the hydrology of the western Niger Delta wetlands: groundwater conditions in the Neogene deposits of the Ndokwa area. Africa Geosciences Review Vol. 18(3) pp 2536. (2011).
[7] Oteze, G. E. water supply, groundwater and flood control in Benin City, presented at the NMGS, Benin chapter sensitization workshop on water resources management and its implications in Benin City, $22^{\text {nd }}$ March. (2011).

[8] Isikhuemen, M. I. and Omorogieva, O. M. Hydrogeochemical and Biophysical Characterization of Groundwater in Eastern Nigeria; A Case Study of Onisha and Environ. Nigeria Journal of Technology Vol.34 (4) (2015).

[9] Omorogieva, 0. M andImasuen, 0. I.Factors Contributing to the Concentration of Heavy Metals in Stream Sediment along Ikpoba River Tributary in Oluku (Upstream) to Ikpoba River Dam (Downstream) and their Implication. Nigeria Journal of Applied Science Vol. 34 pp 187-193. (2016).

[10] Joshua, E. O. and Oyebanjo, O.A. Grain-Size and Heavy Metals Mineral Analysis of River Osun Sediments. Australia Journal of Basic and Applied Sciences, 4(3) pp 498-501 (2010).

[11] Mahavir, S.Heavy Mineral Assemblage of the Pinjor Formation of the Northwestern Himalaya and its Significance in Deciphering the Provenance of the Sediments. J. of Geology, 54: 65-87.Pp 159-162 (2001).

[12] Reyment R. A. Aspect of the geology of Nigeria. University of Ibadan press, Ibadan, Nigeria, (1965).

[13] Short K. C. and Stauble A.J. Outline of the geology of the Niger Delta. Pp 57-59 (1967).

[14] Omorogieva, 0. M. Geoenvironmental Charaterization of Leachates and Hydrogeochemical Properties of Ikhueniro Dumpsite and Environs in Benin City, Edo State. Unpublished Master of Philosophy Thesis, Department of Geology, University of Benin. Pp 138 (2016).

[15] Folk R. L. Review of grain size parameters. Sedimentology, Vol. 4, Pp 73-93. (1937)

[16] Krishna, R. Grain Size Analysis and Engineering Properties of Soils Based on Laboratory Testing. Krishna Reddy, UIC, retrieve online via google, pp 44-59. (2015).

[17] Petti John E. J. Petter, P.E. and Siever, R. Sand and sandstone, $2^{\text {nd }}$ edition Spinger publishers, New York. 1987,Vol 4, pp 99-122

[18] Rao, R. G., Sahoo, P., Panda, N.K. Heavy mineral sand deposit of Orissa. Exploration and Research for Atomic Minerals. Vol. 13 pp 23-52. (2001).

[19] Anfuso, G., M. Achab, G. Cultrone, and F. LopezAguayo. Heavy Mineral Distribution in the Littoral between Sanlucar and Rota". Boletin Instituto Espanol De Oceanogafia, Vol. 15(1-4) pp 245-250. (1999). 
[20] Feo-Codecido, G. Heavy Mineral Techniques and their classification to venezuelan Stratigraphy. Bull Am. Ass Petrol Geol. Vol. 40, pp. 984-1000. (1956).

[21] Folk, R. L. and W.C. Ward. Brazos River bar: A study in the significance of grain size parameters. $J$ Sediment. Petrol. Vol. 27, pp 3-26. (1957).

[22] Ramasamy, P and Karikalan R. Distribution and Percentage of Heavy Minerals in Coastal Geomorphologial Landforms in Palk Strait, Southeast Coast of India Middle-East. Journal of Scientific Research, 5(1): pp 49-53. (2010).

[23] Marshall, B. The present status of zircon, Sedimentology, Vol. 9 pp.119-136. (1967).

[24] Statteger, K. Heavy minerals and provenance of sand: Modeling of lithological end members from river sands of northern Australia and from sandstones Austro- Alpine gossan formation (late Cretaceous). J. Sed. Petrol, Vol. 57. pp 301-310. (1987).

[25] Morton, A. C and Hallsworth, C.R. Processes controlling the composition of heavy mineral assemblages in sandstones. Sed. Geol. Vol.124 pp 329. (1999).

[26] Pender, O. T, Asuen, G.O and Imasuen, O. I. The Environmental Deposition of some Elements Enrichment using Ditch Cuttings Samples from XWell in Oliogo, Onshore Niger Delta. Nigeria Journal of Technology, Vol. 34 (3) pp. 624-630 (2015). 